J. Lake Sci. (湖泊科学), 2012, 24(3): 466-473

http: //www. jlakes.org. E-mail : jlakes@niglas.ac.cn

(C) 2012 by Journal of Lake Sciences

\title{
近百年来新疆博斯腾湖初级生产力的变化"
}

郑柏颖 $^{1,2}$, 张恩楼 $^{1 * *}$, 高 光 ${ }^{1}$

(1: 中国科学院南京地理与湖泊研究所湖泊与环境国家重点实验室,南京 210008)

(2: 中国科学院研究生院,北京 100049 )

摘 要: 本研究选择新疆博斯腾湖不同区域进行沉积岩芯采集. 在 ${ }^{210} \mathrm{~Pb} 、{ }^{137} \mathrm{Cs}$ 定年的基础上,利用漫反射光谱分析了湖 泊沉积物中叶绿素 $\mathrm{a}$ 的含量, 结合沉积速率、烧失量以及开都河的径流量记录等, 探讨近百年来湖泊初级生产力的变化. 结果表明: 开都河的径流量变化对博斯腾湖沉积速率与生产力演化有一定影响, 而人类活动干扰则是影响湖泊初级生产 力演化的主要原因. 1950s 开始的新疆第一次大规模开层活动导致了湖泊的沉积速率及初级生产力开始上升. 沉积物的 沉积速率以及叶绿素 $\mathrm{a}$ 的沉积通量在 1970 年左右出现最高值后下降,这与新疆的第二次大规模旺荒有关, 同时, 周边地 区盐碱地除盐方式的改变对湖泊的生态环境变化也有很大影响. 从 $1980 \mathrm{~s}$ 至今, 由于流域内人类活动干扰增强, 沉积物中 的叶绿素 a 浓度逐渐增加, 湖泊初级生产力呈上升的趋势.

关键词: 叶绿素 $\mathrm{a}$; 初级生产力;湖泊沉积;博斯腾湖

\section{The change of primary productivity of Lake Bosten in Xinjiang over the past 100 a}

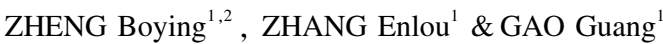

(1: State Key Laboratory of Lake Science and Environment, Nanjing Institute of Geography and Limnology, Chinese Academy of Sciences, Nanjing 210008 , P. R. China)

(2: Graduate University of Chinese Academy of Sciences, Beijing 100049, P. R. China)

Abstract : Two sediment cores were collected in different areas of Lake Bosten in Xinjiang. Based on ${ }^{210} \mathrm{~Pb}$ and ${ }^{137} \mathrm{Cs}$ dating, chlorophyll-a content analyses using the method of diffuse reflection spectrum, and in combination with studies on deposition rate, loss on ignition and runoff records of Kaidu River, the changes of primary productivity of Lake Bosten during the past 100 a were discussed in this paper. The results showed that runoff changes of Kaidu River have some influences on the dry mass accumulation in Lake Bosten, but the impact of human activities is the main reason for the variation of primary productivity. As a result of Xinjiang's first large-scale reclamation in the $1950 \mathrm{~s}$, the deposition rate and the primary productivity of Lake Bosten started to rise. The peak of the deposition rate and chlorophyll-a accumulation rate of the lake sediments appeared in the 1970s, which was related to the Xinjiang's second large-scale reclamation, and the desalting of alkaline soil also played a significant impact on the ecological change of Lake Bosten. From the 1980s to present, with the intensification of the human activities in surrounding areas, chlorophyll-a content of the lake sediments gradually increased, and the primary productivity of Lake Bosten showed an increasing trend. Keywords: Chlorophyll-a; primary productivity; lake sediment; Lake Bosten

近年来,我国许多湖泊在强烈人类活动干扰下富营养化问题凸现 ${ }^{[1]}$, 蓝藻水华暴发等问题严重影响社 会经济发展. 解决湖泊的富营养化问题成为许多湖泊管理的当务之急,而湖泊的科学管理需要了解其长期 的营养水平变化过程与规律、研究历史时期湖泊的初级生产力、明确现今所处的阶段以及预测未来发展方 向. 由于监测数据时间较短, 湖泊沉积在历史时期湖泊生产力演化研究中发挥了重要作用. 湖泊沉积物中许 多指标记录了初级生产力的变化历史,其中沉积物中的色素能较好地指示湖泊生产力的变化过程与湖泊环

* 环保公益性行业科研专项(200909048) 和国家水体污染控制与治理科技重大专项项目 (2009ZX07106-0040) 联合 资助. 2011-07-06 收稿;2011-11-13 收修改稿. 郑柏颖, 男,1987 年生, 硕士研究生; E-mail: zby104@ 126. com.

** 通信作者;E-mail: elzhang@ niglas. ac. cn. 
境演化历史 ${ }^{[2]}$. 色素主要来源于藻类、光合细菌与水生高等植物 ${ }^{[3]}$, 不同的植物具有特定的色素组合, 在植 物体消亡后, 它们体内的一部分色素或衍生物将存在并保存在沉积物中 ${ }^{[4]}$, 它是水生植物生物量的一个最 直接的反应 ${ }^{[5]}$, 因而对湖泊历史时期的初级生产力及营养水平变化过程反应敏感 ${ }^{[6]}$. 同时色素也逐渐被广 泛用于指示湖泊的气候变化、湖泊酸化、紫外线辐射以及自然环境与人类活动对湖泊生态系统的影 响等 ${ }^{[7-10]}$.

新疆的博斯腾湖位于新疆天山南麓巴音郭楞蒙古自治州的焉耆盆地, 深处我国内陆干旱地区, 具有水 资源调控、农田灌溉、工业与生活用水、提供水生动植物资源、流域生态环境保护和向塔里木河下游紧急调 水等多种功能 ${ }^{[11]}$, 对周边地区的发展至关重要. 它曾经是我国最大的内陆淡水湖, 但在自然和人为活动的双 重胁迫下目前已经成为微咸水湖, 且湖泊有机污染日益严重, 存在富营养化的趋势 ${ }^{[12]}$. 由于博斯腾湖水质恶 化与水位降低导致湖滨湿地生境退化, 湖泊生物多样性受到威胁, 严重影响流域内人们的生产生活和塔里 木河下游的生态环境. 鉴于博斯腾湖日益严重的环境问题, 不少学者开展了研究, 目前针对博斯腾湖的研究 主要集中在两个方面: 一方面, 许多学者根据已有短期器测资料, 对博斯腾湖的水环境质量和流域环境变化 及可持续发展进行研究 ${ }^{[13-18]}$. 另一方面, 部分学者利用湖泊沉积岩芯记录研究长时间尺度的全球变化过 程 ${ }^{[19-23]}$. 而利用湖泊沉积记录, 从百年来这一人类活动对自然环境影响最为强烈的时间尺度研究博斯腾湖 初级生产力的变化过程无疑具有重要意义. 本研究通过对博斯腾湖不同区域沉积岩芯中叶绿素 a 的研究, 结合沉积速率及烧失量变化特征, 试图探讨近百年来博斯腾湖初级生产力的变化过程及人类活动对其变化 的影响, 为湖泊科学管理提供依据.

\section{1 材料与方法}

\section{1 研究区概况}

博斯腾湖 $\left(41^{\circ} 56^{\prime} \sim 42^{\circ} 14^{\prime} \mathrm{N}, 86^{\circ} 40^{\prime} \sim 87^{\circ} 26^{\prime} \mathrm{E}\right)$ 属中生代断陷湖, 地处巴音郭楞蒙古自治州博湖县. 东 西长 $55 \mathrm{~km}$, 南北宽 $20 \mathrm{~km}$, 在水位为 $1048.5 \mathrm{~m}$ 时水面面积为 $1210.5 \mathrm{~km}^{2}$, 平均水深 $7.5 \mathrm{~m}$, 最大水深 $17.0 \mathrm{~m}$. 博斯腾湖可分为大小两个湖区, 大湖的西南部分布着一连串的浅水小湖, 盛长芦苇, 称为小湖苇区. 湖区深 居亚欧大陆中心, 属温带大陆性干旱气候, 年均气温 $8.3^{\circ} \mathrm{C}$; 年均降水量 $64.7 \mathrm{~mm}$, 蒸发量 $1881.2 \mathrm{~mm}$. 湖水主 要由开都河补给, 占总人湖地表径流量 $\left(4.55 \times 10^{8} \mathrm{~m}^{3}\right)$ 的 $84.2 \%$, 而开都河既有高山冰川和永久积雪的补 给, 又有中低山季节性积雪融水和夏季降雨的补给, 是唯一的常年性人湖河流. 其余为源于北部天山的乌拉 斯台河、黄水沟、清水河, 曲惠沟和乌什塔拉河等, 出山口后河水被引入灌区, 以地下水的方式补给湖泊. 孔 雀河是唯一的出水流河, 从大湖的西南角出水, 流经铁门关峡谷向西经和什里克南至普惠后折而向东南流 人罗布泊 ${ }^{[14,24]}$.

\section{2 样品采集}

2010 年 9 月利用重力采样器在博斯腾湖大湖区的河口区与深水区 (图 1 ) 分别采集了 2 根平行的短柱 沉积岩芯, 所获得的沉积岩芯水土界面清晰, 表层沉积物未受扰动. 现场以 $0.5 \mathrm{~cm}$ 间隔分样, 样品密封于塑 料袋内带回实验室并在 $4^{\circ} \mathrm{C}$ 条件下冷藏以备分析.

\section{3 年代测定}

样品的年代测定在中国科学院南京地理与湖泊研究所湖泊与环境重点实验室进行. 样品中 ${ }^{210} \mathrm{~Pb} 、{ }^{226} \mathrm{Ra}$ 以及 ${ }^{137} \mathrm{Cs}$ 活度采用美国 EG \& G Ortec 公司生产的高纯锗井型探测器 (HPGe GWL2120215) 测定. ${ }^{137}$ Cs 和 ${ }^{226} \mathrm{Ra}$ 标准样品由中国原子能科学研究院提供, ${ }^{210} \mathrm{~Pb}$ 标准样品由英国利物浦大学做比对标准, 测试误差小 于 $10 \%$.

\section{4 烧失量测定}

本实验参照文献 $[25]$ 中的标准方法进行. 将洗净的 $10 \mathrm{ml}$ 瓷坩埚置于 $105^{\circ} \mathrm{C}$ 烘箱内 $3 \mathrm{~h}$, 取出后在干燥 器中冷却 $1 \mathrm{~h}$, 称重 $\left(M_{\text {eup }}\right)$. 称取一定量的沉积物样品放置于坩埚内, 在 $105^{\circ} \mathrm{C}$ 的烘箱内 $3 \mathrm{~h}$, 取出后放在干燥 器中冷却 $1 \mathrm{~h}$ 后称重 $\left(M_{105}\right)$. 然后将坩埚转移到马弗炉中, 升温至 $550^{\circ} \mathrm{C}$ 后灼烧 $3 \mathrm{~h}$, 取出放置于干燥器中冷 却 $1 \mathrm{~h}$ 后称重 $\left(M_{550}\right)$. 按下列公式计算烧失量 $(L O I)$ : 


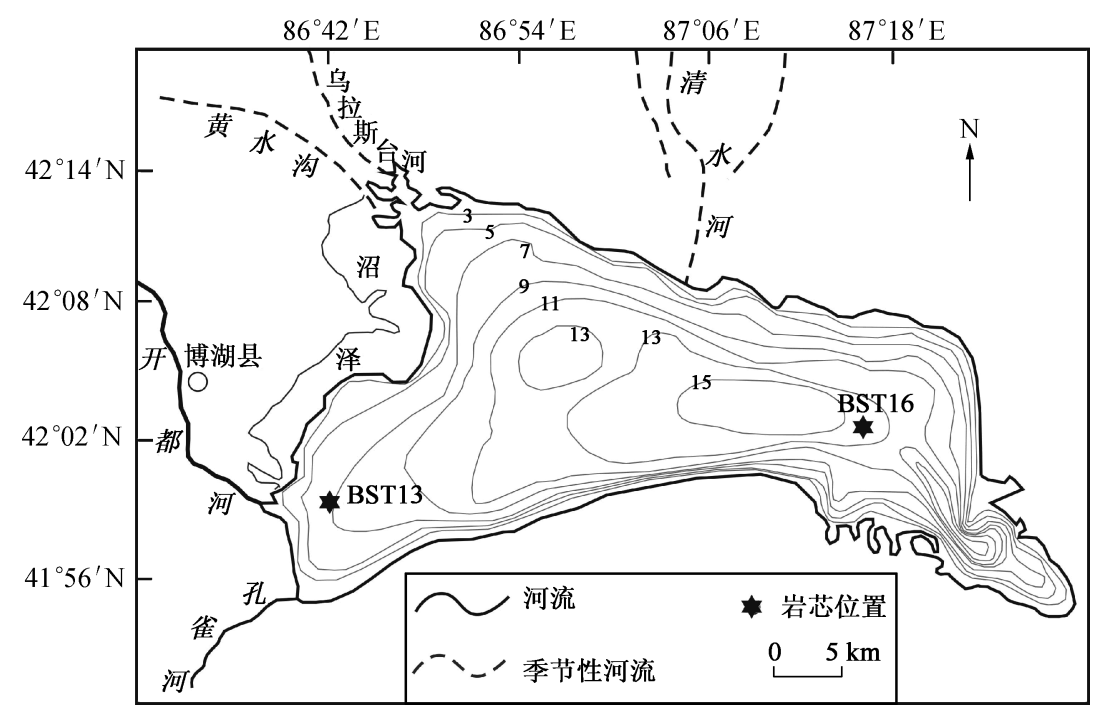

图 1 博斯腾湖采样点位置 ${ }^{[19]}$

Fig. 1 Distribution of sampling sites in Lake Bosten

$$
L O I / \%=\left[\left(M_{105}-M_{550}\right) /\left(M_{105}-M_{\text {cup }}\right)\right] \times 100 \%
$$

\section{5 叶绿素 $a$ 的漫反射光谱方法测定}

目前沉积物色素的分析方法主要有分光光度计法 ${ }^{[6]}$ 及色谱法 ${ }^{[7]}$,但是高效液相色谱法预处理过程复 杂、成本高, 而分光光度计方法预处理时间过长、步骤繁多. 因此,近几年有些学者提出了一些新方法. 本研 究则依据季峻峰等提出的漫反射光谱法进行, 根据沉积物红度数据计算出叶绿素 $\mathrm{a}$ 的一个相对值, 这种方 法具有预处理简单、快速、需要样品量少、成本低等特点,且其结果有较高的可信度 ${ }^{[26-27]}$.

叶绿素 a(Chl. a) 采用季峻峰等 ${ }^{[26-27]}$ 提出的标准方法在 Perkin-Elmer Lambda 900 漫反射光谱仪上测定, 在南京大学表层地球化学国家重点实验室完成. 取一定量新鲜的沉积物样品放置于玻璃片上, 在低温条件 下 $\left(<40^{\circ} \mathrm{C}\right.$ ) 晾干, 经过研磨后, 用无水乙醇将沉积物样品制成泥浆, 并均匀地涂抹在玻璃片上, 低温晾干 (要 求晾干后的样品表面光滑, 无裂隙或空白, 以减小误差). 选择 $400 \sim 1000 \mathrm{~nm}$ 波长对样品进行扫描, 得到样 品在不同的波长上反射的百分比 (以 Spectralon 为标准). 然后计算沉积物样品在 $670 \mathrm{~nm}$ 处的反射峰的深 度,即为叶绿素 $\mathrm{a}$ 浓度的一个相对值. 具体算法见文献 $[26]$.

\section{2 结果}

\section{1 年代确定}

陈发虎等 ${ }^{[19]}$ 根据 Norris 等 ${ }^{[28]}$ 关于中国历史时期核武器的核爆当量的报道,推算出中国 $1960 \mathrm{~s}-1970 \mathrm{~s}$ 新疆博斯腾湖沉积物中 ${ }^{137} \mathrm{Cs}$ 应该有三个蓄积峰, 分别为: 1967-1970 年、1973 年以及 1976 年, 再加上 1963 年全球核爆的高峰期, 这些蓄积峰在 BST13 与 BST16 两个采样点中均比较明显 (图 2a), 可作为定年的时 标. 两个采样点岩芯中的 ${ }^{210} \mathrm{~Pb}$ 活度随深度的增加而呈指数降低, 指示了其较为稳定的沉积环境. 采用 1963 年单个时标的复合模式计算结果与 CRS 模式的计算结果相差不大, 但与已确定的 ${ }^{137} \mathrm{Cs}$ 时标有较大的偏离, 本研究采用多时标的复合模式方法计算年代, 将已确定的时标加人复合模式, 分段计算沉积岩芯的年代, 具 体计算方法见文献 [29].

从沉积速率 (图 3) 来看,BST13 与 BST16 两岩芯具有比较好的一致性,都大致可以分为三个阶段: 1950 年 以前博斯腾湖基本上处于一个较低的平稳的沉积过程, 平均沉积通量在 $0.03 \mathrm{~g} /\left(\mathrm{cm}^{2} \cdot \mathrm{a}\right)$ 左右; 从 1950 年开始 沉积速率缓慢上升, 1960-1980 年为博斯腾湖的沉积高峰期, BST13 最大的沉积速率达到 $0.38 \mathrm{~g} /\left(\mathrm{cm}^{2} \cdot \mathrm{a}\right)$, 


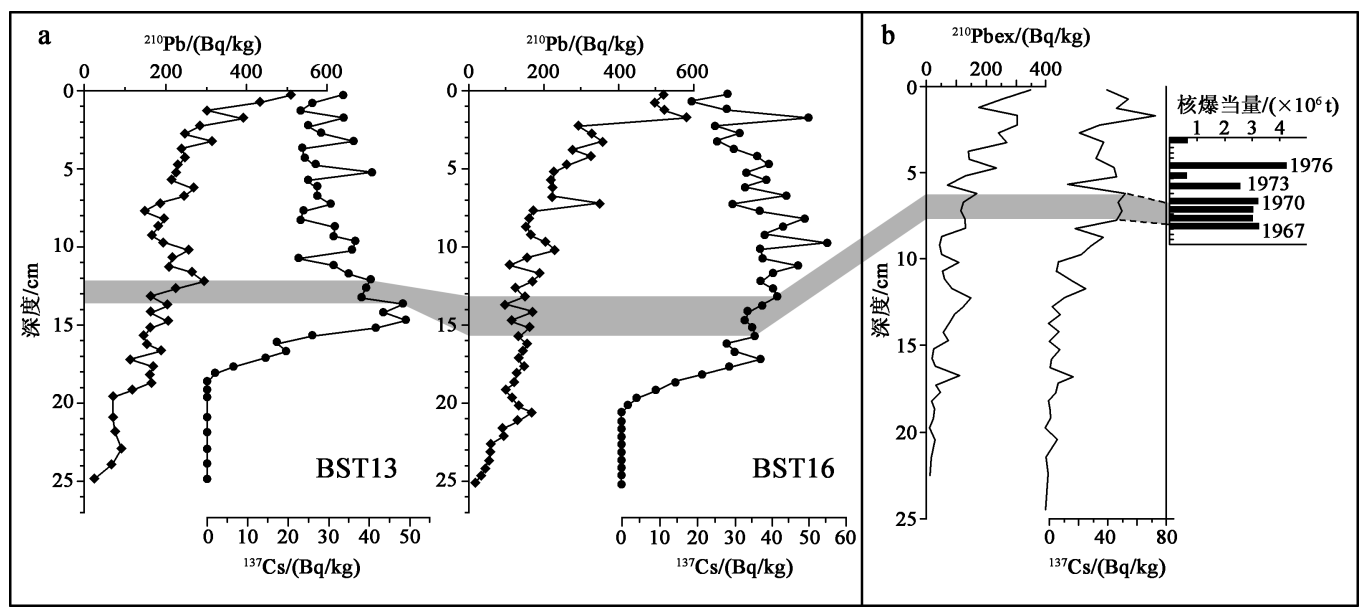

图 2 博斯腾湖 BST13 与 BST16 的 ${ }^{210} \mathrm{~Pb}$ 与 ${ }^{137} \mathrm{Cs}$ 变化序列 (a); 文献 $[19]$ 中 ${ }^{210} \mathrm{~Pb}$ 与 ${ }^{137} \mathrm{Cs}$ 测年结果 $(\mathrm{b})$

Fig. $2{ }^{210} \mathrm{~Pb}$ and ${ }^{137} \mathrm{Cs}$ changing sequence of BST13 and BST16 in Lake Bosten(a), ${ }^{210} \mathrm{~Pb}$ and ${ }^{137} \mathrm{Cs}$ changing sequence in Chen $\mathrm{FH}, 2007$ (b)

而 BST16 的最大的沉积速率达到 $0.59 \mathrm{~g} /\left(\mathrm{cm}^{2} \cdot \mathrm{a}\right)$; 1980 年后, 两个采样点均表现为稳中有升的状态, 1980 年至今 BST13 的平均沉积速在 $0.13 \mathrm{~g} /\left(\mathrm{cm}^{2} \cdot \mathrm{a}\right)$ 左右, BST16 的平均沉积速率却只有 $0.085 \mathrm{~g} /\left(\mathrm{cm}^{2} \cdot \mathrm{a}\right)$ 左右.
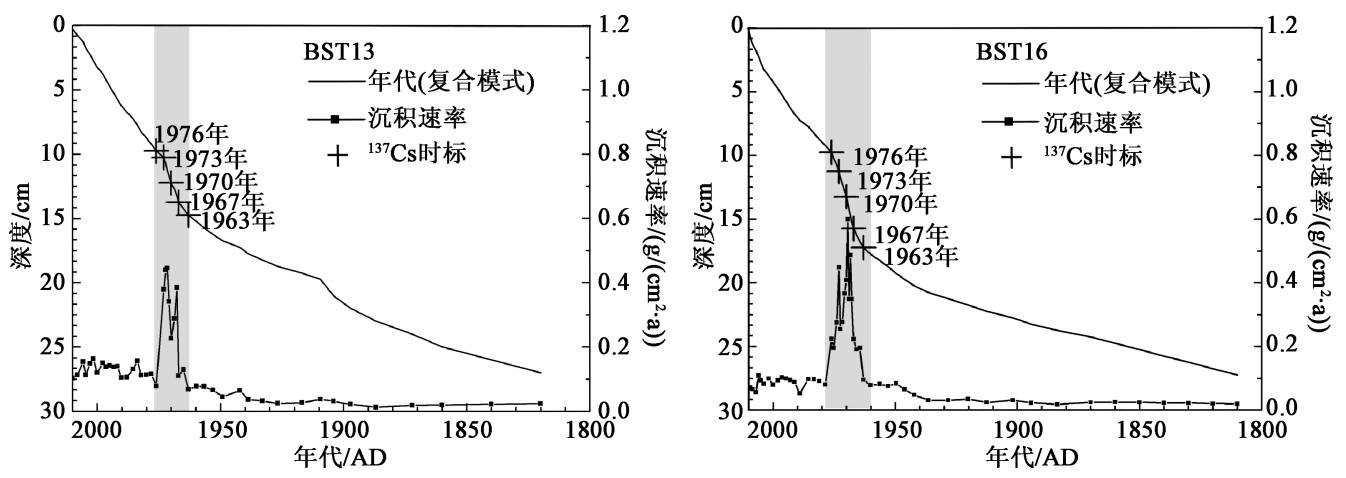

图 3 博斯腾湖两个采样点的年代和沉积速率

Fig. 3 Age-depth plot and dry mass accumulation rate of two sediment cores from Lake Bosten

\section{2 烧失量的变化}

人们通常采用湖泊沉积物中总有机碳含量来反映湖泊的古生产力 ${ }^{[30]}$, Cato ${ }^{[31]}$ 认为在一定条件下, 可以 用烧失量来估算沉积物中的有机质含量. 但以往的研究中较少考虑沉积速率对烧失量的影响. 然而, 仅用烧 失量来指示湖泊初级生产力的变化有一定局限, 特别是历史沉积速率变化较大的湖泊. 对比烧失量 (图 4) 与 沉积速率的变化过程 (图 3) 可以看出, 1960-1980 年间两岩芯均出现沉积高峰, 但是烧失量在此时段内却 处于低谷阶段, 特别是在开都河河口区的 BST13 岩芯中表现更明显. 这种不一致主要是因为沉积速率过快, 大量无机碎屑物质的带人对有机质和叶绿素 a 浓度有较大 “稀释” 作用, 表现为: 当接受相同的有机质沉积 时, 沉积速率越大, 沉积物中的有机质含量越低, 反之亦然. 因而有必要结合沉积速率的变化, 研究生产力的 变化过程, 更准确地反映古生产力水平. 特别是像博斯腾湖这样历史时期沉积速率变化很大的湖泊, 沉积速 率变化的影响更是不可忽略. 本研究通过计算烧失量的沉积通量以去除沉积速率的影响. 计算方法为: 烧失 量的沉积通量 $=$ 烧失量 $\times$ 沉积速率. 

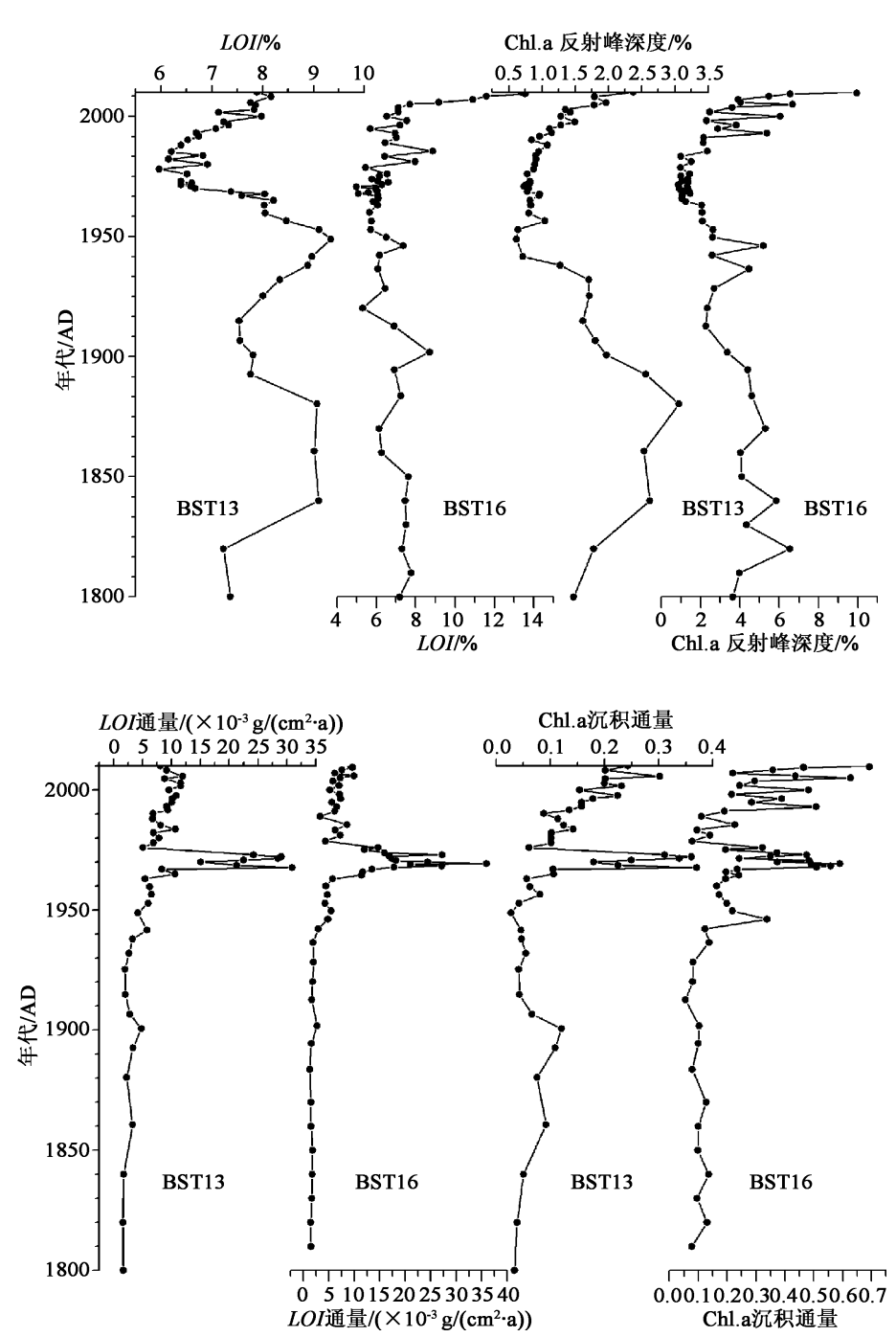

图 4 两岩芯的烧失量与色素及其沉积通量的变化

Fig. 4 Changing sequence of loss on ignition and chlorophyll-a and their accumulation rate of two sediment cores in Lake Bosten

从沉积物中有机质的沉积通量 变化过程 (图 4) 可以看出, 有机质 的沉积通量与沉积速率有较大的相 似性. 1950 年以前两岩芯的有机质 沉积速率都比较低, BST16 基本稳 定在 $1.6 \times 10^{-3} \mathrm{~g} /\left(\mathrm{cm}^{2} \cdot \mathrm{a}\right)$ 左右, 而 BST13 稍高, 在 $2.5 \times 10^{-3}$ $\mathrm{g} /\left(\mathrm{cm}^{2} \cdot \mathrm{a}\right)$ 左右波动. 1950 年以 后, 两个采样点的有机质沉积通量 开始上升, 1960-1980年是博斯腾 湖的沉积的高峰阶段, 也是有机质 沉积通量的高峰时期, BST13 的有 机质沉积通量最高值达到 $29 \times$ $10^{-3} \mathrm{~g} /\left(\mathrm{cm}^{2} \cdot \mathrm{a}\right)$, BST16 的最高值 为 $35 \times 10^{-3} \mathrm{~g} /\left(\mathrm{cm}^{2} \cdot \mathrm{a}\right)$, 在 1980 年左右, 其通量开始大幅降低. 1980 年以后, 两个采样点的变化较 小, 均处于缓慢上升的状态, BST13 $L O I$ 的沉积通量在 $10 \times 10^{-3}$ $\mathrm{g} /\left(\mathrm{cm}^{2} \cdot \mathrm{a}\right)$ 左右, 而 BST16 则在 $7 \times 10^{-3} \mathrm{~g} /\left(\mathrm{cm}^{2} \cdot \mathrm{a}\right)$ 左右.

\section{3 叶绿素 $a$ 浓度变化序列}

目前, 漫反射光谱吸收峰的深 度与叶绿素 $\mathrm{a}$ 的浓度之间并未建 立可靠的转换函数, 因而本研究中 所述的叶绿素 $\mathrm{a}$ 的浓度并非其绝 对值, 而是一个相对值含量. 同样, 沉积速率对叶绿素 a 浓度的影响 也不可忽略, 因而本研究中叶绿素 $\mathrm{a}$ 的沉积通量 $=$ 叶绿素 $\mathrm{a}$ 的相对含 量 $\times$ 沉积速率.

叶绿素 $\mathrm{a}$ 的沉积通量总体变 化趋势与有机质的变化趋势类似, 但其变化幅度较大 (图 4). BST13

在 1950 年以前其沉积通量稍高, 在 1950 年左右达到最低, 而同时期 BST16 的叶绿素 a 的沉积通量则稳定在 一个稳定的低值阶段. 两岩芯自 1950 年开始叶绿素 $\mathrm{a}$ 的沉积速率开始大幅上升, 1960-1980 年为其沉积高 峰, 在 1970 年左右达到最大值后开始下降, 最高值达到 1950 年的 $2 \sim 3$ 倍. 1980 年以后, 两个采样点的叶绿 素 $\mathrm{a}$ 的沉积通量又开始急剧上升,目前基本上与 1960-1980 年间的沉积高峰阶段处于同一水平.

\section{3 讨论}

\section{1 开都河径流量的变化对博斯腾湖沉积速率与生产力演化的影响}

大山口水文站位于焉耆水文站的上游地区, 两地径流量变化趋势相差不大 (图 5), 在 1970 年左右出现 一个径流高峰, 其中大山口水文站 1971 年达到最大值, 为 $45.74 \times 10^{8} \mathrm{~m}^{3}, 1972$ 年焉者水文站的径流量达到 $27.4 \times 10^{8} \mathrm{~m}^{3}$, 径流量大, 必然导致带人湖泊的泥沙增加. 1980-2002 年两地的径流量也呈现缓慢上升的状 
态, 与沉积速率以及色素、有机质的沉积通量表现出相似的变化过程, 因而开都河径流量的变化与湖泊沉积 的变化有一定的关系.

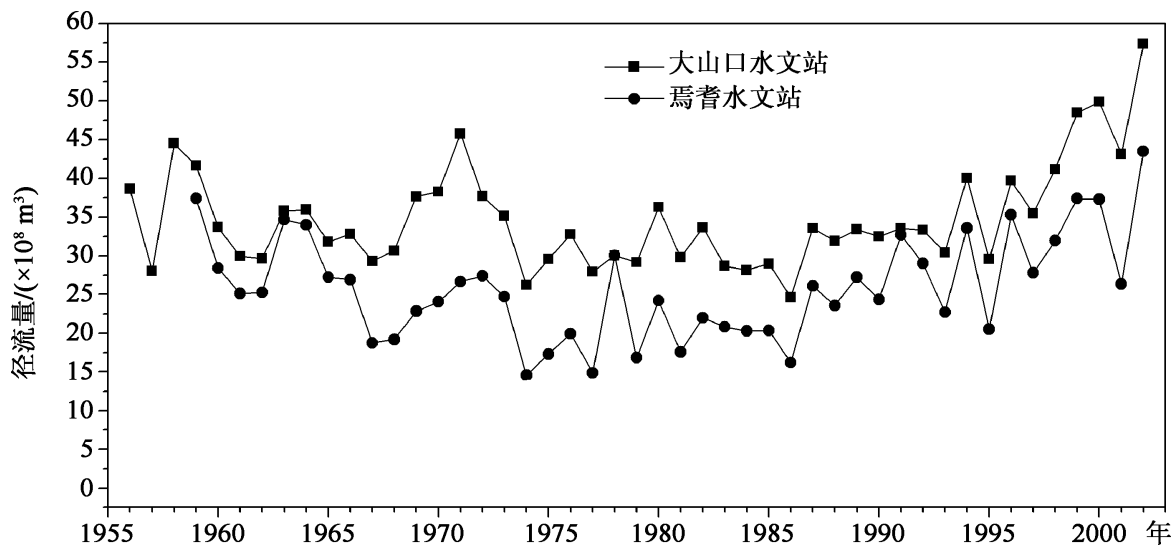

图 5 大山口水文站与焉耆水文站的径流量变化

Fig. 5 Runoff changes of Dashankou and Yanqi hydrological stations

但开都河的径流量变化幅度基本在 30\% 以内,而 1970 年左右的沉积速率超过 1950 年沉积速率的 3 倍, 径流量的年际变化远比沉积速率的幅度小, 因此可认为近百年来自然因素不是引起沉积过程变化的主 要原因, 流域内人类活动, 特别是农业活动的强度变化与耕作方式改变对沉积速率变化起主要作用. 因而, 从百年尺度上看, 博斯腾湖的沉积速率与叶绿素 $\mathrm{a}$ 的变化是自然与人类活动双重作用下的结果, 自然环境 改变对其变化过程有一定影响,但是在自然变化基础上叠加的人为影响才是导致其历史沉积速率变化较大 的主要原因.

\section{2 博斯腾湖流域的农业发展历史与湖泊初级生产力变化的关系}

引起博斯腾湖水质污染的主要原因是灌区农业排盐水的污染 ${ }^{[32]}$. 博斯腾湖流域年降雨量少而蒸发量 大,在这种温带干旱大陆性气候下容易形成盐碱地, 不适合农作物的生长. 在盐碱地上耕植农作物就必须降 低土壤中的盐碱成分, 其中一个行之有效而又成本低廉的方法就是引用大量的河水, 以水压盐. 开都河下游 地区及博斯腾湖北部分布大量农田. 农业废水的排人导致人湖的泥沙、有机质、营养盐等增加, 加快湖泊的 沉积速率的同时,也提高湖泊的初级生产力.

从历史时期农业发展强度的变化来看, 从 1950s 初到 1960s 中期为新疆大规模开垦的第一个高峰期,农 田垦殖面积迅速增加, 多分布于水土条件较好的冲积扇和洪积扇泉水溢出带上. 1960s 末期到 1980s 中期, 为新疆大规模水土开发的第二个高峰期, 片面强调以粮为纲, 长期乱开草场、滥伐森林、湖滨开荒等掠夺式 的经营,一方面致使草地、沼泽地、超旱生灌木半灌木荒漠、多汁木本盐柴类荒漠向农田的转换, 农田面积大 规模的扩张, 而盆地内部大块成片的草地完全消失; 另一方面, 致使农田、草地向盐碱地和各种荒漠转换. 1980s 中期以后, 当地政府采取了一系列措施, 严格限制盆地的开荒面积, 加大盆地田间管理,农田的扩张幅 度以及土地盐渍化程度较前一阶段均有所减小 ${ }^{[33]}$.

另外,周边地区盐碱地上洗盐方式的改变对沉积速率的变化有至关重要的作用. 早期开㞸盐碱地多采 用无排水压盐方式, 土壤中的盐分并没有排走, 而是淋洗到土壤下部. 随着地下水位上升和地表强烈蒸发, 原先被淋洗到剖面下层的盐分重新返回到地表 ${ }^{[13]}$. 从 1950s 至 $1960 \mathrm{~s}$ 中期, 人类活动虽然比较剧烈,但农业 活动对湖泊的生态环境并无太大影响. 1960s 中期以后加强了排水工程建设,大量的土壤盐分通过洗盐和农 田排水进入湖区 ${ }^{[13]}$, 因而, 1960 年的矿化度为 $0.383 \mathrm{~g} / \mathrm{L}$, 而 1975 年的矿化度则快速上升到 $1.4 \mathrm{~g} / \mathrm{L}$, 这说明 周围农田除盐方式的改变与博斯腾湖的生态环境变化有很大关系, 同时沉积速率在该时期的迅速攀升亦与 此有关.

从 1950 年开始,博斯腾湖的沉积速度开始加快, 叶绿素 $\mathrm{a}$ 的沉积通量也开始增加,这对应于新疆大规模 
开剭的第一个高峰期. 1960-1980 年出现了一个沉积速率和初级生产力的高峰期, 时间上也对应于第二次 大规模垦荒的高峰期. 大规模开垦荒地一方面会导致湖泊的沉积速率加快, 另一方面也向湖泊输人大量的 有机质及其营养盐, 导致湖泊的初级生产力明显提高. 从 1980 年开始, 虽然当地政府加强管理,但是随着该 地区人口增长与经济的快速发展, 人类活动对自然的干扰强度加大, 沉积物中的有机质含量增加, 叶绿素 $\mathrm{a}$ 的沉积通量也相应增加, 湖泊的初级生产力不断提高.

在 1980 年后, 两个采样点叶绿素 $\mathrm{a}$ 的沉积通量增长速度较沉积速率以及有机质的沉积通量高, 说明 1980 年后单位质量的有机质所含叶绿素 $\mathrm{a}$ 的比例增加. 单位有机质的色素含量也是湖泊初级生产力变化的 一个指标 ${ }^{[9]}$, 因而, 这个比值的上升也说明了博斯腾湖在 1980 年后经历了一个初级生产力缓慢上升的 过程.

\section{4 结论}

多种指标研究表明近百年来博斯腾湖在自然与人类活动干扰的双重胁迫下, 湖泊的初级生产力经历了 两次上升过程,但从百年尺度上看, 自然环境变化对博斯腾湖的沉积过程的影响有限, 而影响沉积演变的主 要因素是人类活动的强烈干扰. 从 1950 年开始, 沉积速率与烧失量、Chl. a 的沉积通量等指标均开始上升. 说明在人类的强烈干扰下湖泊环境开始退化, 湖泊的初级生产力开始提高. 1960-1980 年叶绿素 a 的沉积 通量和沉积速率等指标均出现了峰值, 这与开都河径流量处于历史高峰期有一定关联, 但主要是由新疆地 区的第二轮大规模层荒使得大量的泥沙、有机质、营养盐等排人湖泊所致. 同时, 流域内以水压盐转变为以 水洗盐,这种去盐方式的改变对博斯腾湖的生态环境变化有很大影响. 加之该时期周边居民环境保护意识 不强,政府也未对湖泊实施科学有效的管理,不合理、高强度的开发与利用对博斯腾湖湖泊水环境产生极大 影响, 导致了湖泊沉积速率加快, 湖泊初级生产力提高. 1980s 后虽然当地政府加强了湖泊的管理与合理利 用, 但是人口增长以及经济快速发展的压力又导致了湖泊的初级生产力开始缓慢抬升. 虽然博斯腾湖目前 整体的初级生产力不高, 未出现类似我国东部许多湖泊的蓝藻水华暴发等严重问题, 但是从沉积记录所反 映的初级生产力变化过程来看, 博斯腾湖有向富营养化发展的趋势, 因而有必要加强湖泊的科学管理, 防止 其环境进一步退化, 以实现可持续发展.

致谢: 龚志军、汤祥明、迟克续等参加野外工作, 季峻峰教授、何同在实验中提供指导与帮助, 夏威岗高级工 程师和刘恩峰在年代测定与算法方面提供帮助,在此一并表示感谢.

\section{5 参考文献}

[ 1 ] 秦伯强, 朱广伟. 长江中下游地区湖泊水和沉积物中营养盐的赋存、循环及其交换特征. 中国科学: D 辑, 2005, 35 (增刊 II ) : 1-10.

[ 2 ] Reuss N, Leavitt PR, Hall RI et al. Development and application of sedimentary pigments for assessing effects of climatic and environmental changes on subarctic lakes in northern Sweden. Journal of Paleolimnology, 2010, 43 : 149-169.

[ 3 ] Meyers PA, Teranes JL. Sedimentary pigments. In: Last WM, Smol JP eds. Tracking environmental changes using lake sediment, Volume 3: Terrestrial, algal, and siliceous indicators. Dordrecht: Kluwer Academic Publishers, 2001: 295-325.

[4] 沈 吉, 薛 滨, 吴敬禄等. 湖泊沉积与环境演化. 北京: 科学出版社, 2010: 250-251.

[ 5 ] Guilizzoni P, Bonomi G, Galanti G et al. Relationship between sedimentary pigments and primary production: evidence from core analyses of twelve Italian lakes. Hydrobiologia, 1983, 103 : 103-106.

[ 6 ] Swain EB. Measurement and interpretation of sedimentary pigment. Freshwater Biology, 1985, 15: 53-75.

[ 7 ] Leavitt PR, Vinebrooke RD, Donald DB et al. Past ultraviolet radiation environments in lakes derived from fossil pigments. Nature, 1997, 388: 457-459.

[ 8 ] Clough LM, Renaud PE, Ambrose WG. Impacts of water depth, sediment pigment concentration, and benthic macrofaunal biomass on sediment oxygen demand in the western Arctic Ocean. Canadian Journal of Fisheries and Aquatic Sciences, 2005, 62: 1756-1765

[ 9 ] Reuss N, Conley DJ, Bianchic TS. Preservation conditions and the use of sediment pigments as a tool for recent ecological 
reconstruction in four Northern European estuaries. Marine Chemistry, 2005, 95 : 283-302.

[10] Kowalewske G. Algal pigments in Baltic sediments as markers of ecosystem and climate changes. Climate Research, 2001, 18 : 89-96.

[11] 金海龙, 王晓峰, 王 哲等. 新疆博斯腾湖资源开发与环境保护研究. 水土保持研究, 2002, 9(3): 58-61.

[12] 李家科. 博斯腾湖水环境容量及污染物排放总量控制研究 [学位论文]. 西安: 西安理工大学, 2004.

[13] 周成虎, 罗格平, 李 策等. 博斯腾湖环境变化及其与焉耆盆地绿洲开发关系研究. 地理研究, 2001, 20(1): 1423.

[14] 夏 军, 左其亭, 邵诚民. 博斯腾湖水资源可持续利用一一理论 - 方法 - 实践. 北京: 科学出版社, 2003: 3-17, $31-39,50-53$.

[15] 程其畴. 博斯腾湖研究. 南京: 河海大学出版社, 1995: 108-144.

[16] 孙占东, Opp C, 王 润等. 博斯腾湖流域山区地表径流对近期气候变化的响应. 山地学报, 2010, 28(2): 206-211.

[17] 李卫红, 陈跃滨, 徐海量等. 博斯腾湖的水环境保护与可持续利用对策. 地理研究, 2003, 22(2): 185-191.

[18] 王 润, 孙占东, 高前兆. 2002 年前后博斯腾湖水位变化及其对中亚气候变化的响应. 冰川冻土, 2006, 28(3): 324-329.

[19] 陈发虎, 黄小忠, 张家武等. 新疆博斯腾湖记录的亚洲内陆干旱区小冰期湿润气候研究. 中国科学: D 辑, 2007, 37 (1) : 77-85.

[20] 陈发虎, 黄小忠, 杨美临. 亚洲中部干旱区全新世气候变化的西风模式一以新疆博斯腾湖记录为例. 第四纪研 究,2006, 26(6) : 881-887.

[21] 黄小忠. 新疆博斯腾湖记录的亚洲中部干旱区全新世气候变化研究 [学位论文]. 兰州: 兰州大学, 2006.

[22] 张成君, 郑绵平, Prokopenko A 等. 博斯腾湖碳酸盐和同位素组成的全新世古环境演变高分辨记录及与冰川活动 的响应. 地质学报, 2007, 81(12): 1658-1671.

[23] 杨美临. 博斯腾湖多代用指标 (侧重硅藻) 记录的全新世气候变化模式 [学位论文]. 兰州: 兰州大学, 2008.

[24] 王苏民, 窦鸿身. 中国湖泊志. 北京: 科学出版社, 1998: 345-346.

[25] 朱广伟, 秦伯强, 高 光. 灼烧对沉积物烧失量及铁、磷测定的影响. 分析实验室, 2004, 23(8): 72-76.

[26] Ji JF, Shen J, Balsam W et al. Asian monsoon oscillations in the northeastern Qinghai-Tibet Plateau since the late glacial as interpreted from visible reflectance of Qinghai Lake sediments. Earth and Planetary Science Letters, 2005 , 233 : $61-70$.

[27] Ji JF, Balsam W, Shen J et al. Centennial blooming of anoxygenic phototrophic bacteria in Qinghai Lake linked to solar and monsoon activities during the last 18,000 years. Quaternary Science Reviews, 2009, 28 : 1304-1308.

[28] Norris RS, Burrows AS, Fieldhouse RW. British, French, and Chinese nuclear weapons. Boulder: Westview Press, 1994 : 333-336.

[29] Appleby PG. Chronostratigraphic techniques in recent sediments. In: Last WM, Smol JP eds. Tracking environmental change using lake sediments, volume 1: basin analysis, coring, and chronological techniques. Dordrecht: Kluwer Academic Publishers, 2001: 171-196.

[30] 沈 吉, 张祖陆, 孙庆义等. 南四湖沉积剖面中色素与有机碳同位素特征的古环境意义. 湖泊科学, 1998, $10(2): 17-22$.

[31] Cato I. Recent sedimentological and geochemical conditions and pollution problems in two marines areas in southwestern Sweden. Uppsala: SARIAE, 1977, 6: 1-158.

[32] 徐海量, 陈亚宁, 李卫红. 博斯腾湖湖水污染现状分析. 干早区资源与环境, 2003, 17(3): 95-97.

[33] 张 俊, 周成虎, 李建新. 新疆焉者盆地近 40 年土地利用与土地覆被演化. 资源科学, 2004, 26(6): 31-37. 